\title{
Telehealth as a Panacea Amidst Global Pandemic (COVID-19) in Africa
}

\author{
Afrika'da COVID-19 Pandemisine karşı Alternatif Bir Çözüm Olarak Telesağlık Hizmetleri
}

\author{
Gloria Nnadwa ALHASSAN ${ }^{1}$ \\ (D) 0000-0002-0316-7485 \\ İlknur ÖZTÜRK ${ }^{2}$ \\ (D) 0000-0002-2079-0383 \\ Festus Fatai ADEDOYIN ${ }^{3}$ \\ (D) 0000-0002-3586-2570 \\ Festus Victor BEKUN ${ }^{4}$ \\ (D) 0000-0003-4948-6905
}

\begin{abstract}
${ }^{1}$ İstanbul Gelişim University Vocational School of Health Services, İstanbul, Turkey

${ }^{2}$ Çağ University Faculty of Economics and Administrative Sciences, Mersin, Turkey

${ }^{3}$ Bournemouth University Department of Computing and Informatics, United Kingdom

${ }^{4}$ İstanbul Gelişim University Faculty of Economics, Administrative and Social Sciences, İstanbul, Turkey
\end{abstract}

\section{Corresponding Author Sorumlu Yazar \\ İlknur ÖZTÜRK \\ ilknurozturk@cag.edu.tr}

Received / Gelis Tarihi : 15.01.2021 Accepted / Kabul Tarihi : 14.03.2021 Available Online /

Çevrimiçi Yayın Tarihi : 17.03.2021

\begin{abstract}
Technology is disrupting bringing up a better innovation and strengthening the healthcare services. Telehealth is one of these services. Telehealth can help in times of emergency situations as well as reducing morbidity caused by other diseases other than coronavirus and also constraining its spread as well as sustaining the country's economic development. Although, telehealth is a disruptive innovation, this article aimed to point out why Africa and rest of the world need telehealth to structure out the management of the three phases of health crises (pre, during and post-crises) that must be address to help in economic sustainability, increase accessibility to healthcare and increase in quality of life which in turn reduces costs and easy access to healthcare services either incommunicable, non-communicable, or disastrous situations in the African region. In fighting an outbreak such as this, our study finds that the government of African nations should guarantee all health experts get fitting instruction and preparing; present telehealth accreditation for wellbeing experts; give subsidizing which satisfactorily takes care of the expense of giving telehealth; overhaul clinical models of care; bolster all partners with a viable correspondence; and finally, change the board technique while setting up frameworks to oversee telehealth benefits on a standard premise. Keywords: Telehealth; Africa; COVID-19; global pandemic; coronavirus.
\end{abstract}

\section{öz}

Teknolojide yaşanan gelişmelerin getirdiği inovasyon, diğer birçok sektörle birlikte sağlık sektöründe de sağlık hizmetlerinin kalitelendirilmesi konusunda kullanılmaktadır. Sağlık sektöründe uygulanan teknolojik uygulamalardan birisi de telesağlık hizmetleridir. Telesağlık hizmetleri acil durumlar başta olmak üzere diğer birçok hastalıkta ve son dönemde yaşamakta olduğumuz koronavirüs pandemisinin yayılmasını azaltmaya yönelik uygulamalar ile daha fazla gündeme gelmekte ve bu olumlu özellikleri nedeniyle de sürdürülebilir kalkınma süreçlerine önemli katkılar sağlamaktadır. Bu çalışmanın amacı Afrika'dan başlamak üzere tüm dünyada uygulanan telesağlık hizmetlerinin pandemi öncesi, pandemi sürecinde ve pandemi sonrası dönemlerde neden telesağlı hizmetlerine etkin şekilde başvurulması gerektiğinin altını çizmektir. Gerçekten de Afrika'nın ulaşılabilen, ulaşılamayan ya da doğal afetler yaşanan birçok bölgesinde etkin, düşük maliyetli, yaşam kalitesinin yükseltilmesini hedefleyen sağlık hizmetlerine daha yüksek erişim sağlamanın yanında ekonomik sürdürülebilirliği de amaçlayan çok güçlü imkanlar sağlaması dolayısıyla telesağlı hizmetleri oldukça dikkat çekici şekilde uygulanmaktadır. Bu çerçevede bu çalışmamızda halen yaşamakta olduğumuz pandemi gibi salgınların yaşanması durumunda tüm Afrika ülkelerinden başlayarak sağlık çalışanlarının telesağlık hizmeti verme konusunda hazırlıklı olması; telesağlık hizmetlerinin tüm ülkelerde akredite olması; telesağlık hizmetlerinin etkin şekilde verilebilmesi için hükümetlerce sübvansiyonların sağlanması; klinik bakım modellerinin gözden geçirilmesi ve son olarak, standart telesağlık hizmetlerini denetlemek için tedbirler, kurallar ve regülasyonların oluşturulması süreçlerinde yönetim kurulu tekniğinin değiştirilmesi hizmetlerin kalitelenmesi açısından üzerinde durulan konular olmuştur.

Anahtar kelimeler: Telesağlık; Afrika; COVID-19; pandemi; coronavirus. 


\section{INTRODUCTION}

The spread and number of cases from a zoonotic origin virus called 2019-novel coronavirus (2019-nCoV) are alarming (1). The World Health Organization (WHO) declared the spreading contagious virus as the first pandemic ever happen by the coronavirus family as of 11 March 2020 (2). WHO risk assessment for the pandemic is "globally=very high", recorded African Region confirmed cases is 46,829 as of 12 May 2020 according to the WHO coronavirus disease 2019 (COVID-19) Situation Report-113. Government, business, industries, and public sectors are all in a terrific situation and not prepared for the crises especially for the Africa Health services. Seeing the havoc done by COVID-19 especially in health service and global economy, governments are getting set for the worst (3). COVID-19 is a respiratory pandemic, which means most of the patients are vulnerable to the virus particularly geriatrics, chronic obstructive pulmonary disease (COPD), asthma, and immunodeficiency (4).

Technology is disrupting bringing up a better innovation and strengthening the healthcare services, Telehealth has been in existence but with limited impact due to lack of knowledge about its potential, unwillingness to accept the new system and many more factors both in developed and developing countries. Health Resources and Services Administration described "telehealth" in a whole as involving electronic and telecommunications technologies to "support and promote long-distance clinical health care, patient and professional health-related education, and public health and administration." (5). Telemedicine (telecare) is a subset of telehealth, the Centers for Medicare \& Medicaid Services explains "telemedicine" systematically as activities involving "two-way, real-time interactive communication between the patient and the physician or practitioner at a distant site." (6). COVID-19 is a communicable virus which most government has declared quarantine to reduce face to face contact even in the hospitals. Healthcare service is a necessity for the population in disasters, crises, or pandemic in order to avoid a long time a decrease in quality of life. Telehealth is an essential tool that can help in the management of patients monitoring, prescription, and diagnoses that won't require a laboratory test as well as reducing long hour hospital queue, exposure to the coronavirus, hospitalacquired infections, hospital admission, and re-admissions thus increasing social distancing as one of the major factors in constraining the virus from spreading $(3,7)$.

According to the WHO African region, 2018 edition, Atlas of African health statistics, most of the countries in the African region did not meet the target of the Millennium Development Goals (MDGs). The WHO region classify Africa as one of the sixth in its region with $2.6 \%$ estimated annual population growth speed, much higher than Eastern Mediterranean, South-East Asia, Americas, Western Pacific, and Europe with the respective percentage 2.0\%, 1.3\%, $1.1 \%, 0.7 \%$, and $0.3 \%$. However considering the population of Africa, Nigeria was classified as sixth of the most densely populated country in Africa Region. In Comparison to other WHO region in 2015, African had the lowest healthy life expectancy although with a decreased rate of crude birth and death (8). Africa region's healthy life expectancy, health services and improvements in quality of life can be improved and strengthen with telehealth in the era of COVID-19.
This article aimed to point out why African and rest of the world need telehealth to structure out the management of the three phases of health crises (pre, during and postcrises) that must be address to help in economic sustainability, increase accessibility to healthcare and increase in quality of life which in turn reduces costs and easy access to healthcare services in communicable or non-communicable disease settings, or disaster situations in the African region.

\section{TELEHEALTH AS A PANACEA}

Telehealth can help in times of emergency situations as well as reducing morbidity caused by other diseases other than coronavirus and also constraining its spread as well as sustaining the country's economic development. Telehealth and telemedicine has previously been applied in the past cases of pandemic and epidemic situations (3). Especially in developed countries, which proved a significant positive result in the country's economic and health outcome. Doarn et al. (9) reported that telemedicine has been a source of aid to governments in a disastrous situation for the past previous years. Since 2013 the North Atlantic Treaty Alliance (NATO), an international military alliance for support, integrated a multinational Telemedicine System with evidential positive results in various crises. Through which teleconsultant and other health support were achieved (10). China decided to focus on telehealth and electronic collaborative medical services after the 2003 severe acute respiratory syndrome (SARS) epidemic outbreak (11).

McDowell et al. (12) conducted a 12-week pilot schemed study on 21 COPD patients by uploading a telehealth system with each patient personal information, quality of life (QoL) was measured by St. George's Respiratory Questionnaire (SGRQ) which displayed a significant improvement in COPD patients and patients acknowledging the scheme as a successful one. This was supported by Koulouri et al. (13) an investigated study of QoL among people working in Shipbuilding Industry compared with a control group. Telemetry technique was used which transmit the message immediately to the specialist and diagnoses is made with immediate effect in accordance with the Global Initiative for Chronic Obstructive Lung Disease (GOLD) guidelines, most workers in the ship zone had advanced-stage COPD compared with the general population (control) without knowing. Health experts have seen the fatal effect of late diagnosing of COPD and so telemetric was introduced for fast detection of COPD to avoid the fatal effect and increase in quality of life through telehealth more than the traditional method because of the easy accessibility to the physicians.

Telehealth can decline the rate of re-hospitalization, mortality rate as well as cost and time-saving. Biermann et al. (14) staged a prospective randomized trial with 43 diabetic patients to access if telemanagement has a significant positive impact on time and cost-saving. The result indicated a substantial amount of time can be secured compare to hospital face-face visit, the cost analysis revealed a cost saving of $\approx 650$ EURO per year per patient if telehealth system is applied, the study concluded that telehealth has a positive impact on time and cost 
saving for both physician and the patient. Goldberg et al. (15) pilots randomized controlled trials that involved 208 patient with Class III-IV New York Heart Association heart failure stage, the study investigated the impact of the telehealth home monitoring system for 6 months. The result indicated a negative outcome in the patient rehospitalization rate but a significantly positive reduction in the mortality rate by $56.2 \%$. The Cochrane A review conducted by Inglis et al. (16) validates the results of Goldberg et al. (15), the study pointed out a significant decline in hospital re-admission rates among heart failure patients that received telemedicine. Kim et al. (17) analyzed the key role of telemonitoring in QoL, distress, and anxiety randomly in advance cancer outpatient. The result indicated an increase in QoL, Karnofsky score (32 to 66) and a decrease in suicidal attempts by using the telehealth system.

Furthermore, telehealth plays a crucial role in the psychological effect of the COVID-19 pandemic. Telehealth or more precisely telemental health services is the practical accurate feasible system to use in supporting patients, family members, nonclinical staff, and health service providers during this pandemic. Psychological symptoms accompany by the pandemic have already been observed in populations (governments, students, workers, and families). Stress due to the fear of recession the pandemic may induce due to shut down of businesses, industries, and unemployment (18). If these psychological effects are ignored and unattended to, this may have a longterm health effects on the population (19). Telemental system have shown significant positive effects in psychological distress in diverse ways especially in depression and anxiety (20), post-traumatic stress disorder (PTSD, 21). Some telemental channels have been used successfully and proven to be an effective channel in COVID-19 pandemic, videoconferencing (22) and online forum/service (23). 2019-nCoV was first prominent in China, China government has taken an active step into implementation of telehealth system by providing psychoeducation, monitoring, counseling and training of the population through online podiums, e.g hotline, WeChat, and Tencent QQ (18). In the study of Nicolaidis et al. (24), a telemedicine program is applied in Greece aiming at the improvement of primary health services offered to Greek citizens, especially of remote and rural area. According to their results, participants admitted that Vodafone Telemedicine Program results in more efficient primary healthcare services and improves the patients' QoL.

Health care stakeholders need to reconsider and reclassify which impairment is imperative and which can be changed to non-face-to-face care (telehealth, 25). The traditional care (face-to-face) has a crucial disadvantage in constraining the COVID-19 pandemic (26). The former (telehealth) promotes social distancing and reduced cost, in contrast to the latter (face-to-face). Developing and developed countries need to implement the era of telehealth system to strengthen healthcare, build a healthy population, and increase in economic growth. Hollander and Carr (27) investigate telehealth impact in COVID-19 and reported that about 50 U.S health care systems have already implemented and uncovered the positive impact of telehealth system. Telehealth gives a flexible forum to caregiver or medical specialist and its patient to schedule a suitable time for video consultation while at home to avoid in-person travel, cost, time-saving and promoting social distancing as COVID-19 is constrained. Mercy Virtual Care Center, Sutter Health, and Sentara Healthcare implement the use of the electronic intensive care unit (eICU) to allow caregivers to remotely monitor the status of about 60-100 ICU patients in multiple diverse hospitals. Telehealth provides higher medical support by the caregivers allowing monitoring, consultation, prescription, and treatment of other diseases other than the pandemic with easy accessibility.

\section{CHALLENGES AND INTERVENTION TO TELEHEALTH}

Telehealth is disruptive innovation. A behavioral, willingness, acceptance, readiness, and education change is needed among physicians, patients and the governmental sector to support the new approach of care. Telehealth requires clinicians to switch from the traditional way of care and show a willingness to learn the new model of health care (28). The clinicians regulation to telehealth relies on them recognizing the potent, effectiveness, safety, strength and importance of telehealth to the health care stakeholders (29). Is expected that clinicians lack knowledge and familiarity to the telehealth system because there is little attention or limited telehealth training for medical, nurses, caregivers and allied health pre-registration curricula (30). This makes it difficult for stakeholders to switch or show willingness.

Health behavioral change for healthcare stakeholders reluctance to switch to the new system should be evaluated with the trans theoretical model, these model of health behavior change comprises of six stages: precontemplation, contemplation, determination, action, relapse, and maintenance (31). Marcus et al. (32) conducted a self-efficacy behavioral change study on a sample of 1,063 government workers and 429 healthcare employees in hospital, the analysis result signified employees at different stages of readiness, only 34-39\% of employees reach the maintenance stage while others didn't. Tailoring intervention should be considered as part of the health behavioral change to the telehealth system. Lustria et al. (33) carried out an analysis with metaanalysis technic to compare the impact of tailored and nontailored web-based interventions on health behavioral change, the analyzed result indicated a significant effectiveness in the tailored intervention compared with the control condition while Noar et al. (34) obtained similar result with the same method. Emphatically Rakowski (35) states in his study that a good successful tailoring health intervention should focus on "focal point" as a foundation. Continuous adherence and involvement of behavioral analyst will yield a significant result in the implementation of the interventions.

Appropriate founding is a necessity for telehealth to function at a maximal level, traditionally limited founding has been the source and blame for poor healthcare services (36) especially in developing countries. According to the WHO world health report, most of Africa countries did not meet the MDGs goal by the allocation of $15 \%$ of the government's expenditure into the health sector. For the appropriate emergency implementation of telehealth in COVID-19 pandemic, a temporary founding allocation of health expenditure is needed. 


\section{CONCLUSION}

Telehealth system will have a positive impact on strengthening the healthcare system, impact on healthcare stakeholders, governments and population, providing new opportunities for better health care forum between the physicians and patient, reliable upgrade infrastructure and building a healthier population, lower cost and growth in the country economy in daily practices and emergency crises as highlighted by Klein and Busis (26).

Consequently, supportive health policies should be made by policymakers. To start with, while we will be unable to precisely foresee the planning of cataclysmic events and irresistible pandemics, we can be certain that the end to such outbreaks is not near. Hence, the COVID-19 experience is certainly not a first, and nor will it be the last. Telehealth has a basic job in crisis reactions. Focal points of telehealth incorporate the capacity to: quickly send huge quantities of medical supplies; encourage triage so cutting edge suppliers are not overpowered with new introductions; flexibly clinical administrations when nearby facilities or emergency clinics are harmed or incapable to fulfill a need, and lessening the danger of transferable infections which are transmitted by individual-to-individual contact.

In summary, the government of African nations should, in this way, guarantee all wellbeing experts get fitting instruction and preparing; present telehealth accreditation for wellbeing experts; give subsidizing which satisfactorily takes care of the expense of giving telehealth; overhaul clinical models of care; bolster all partners with a viable correspondence; and finally, change the board technique while setting up frameworks to oversee telehealth benefits on a standard premise.

Ethics Committee Approval: Since our study was a review, ethics committee approval was not required.

Conflict of Interest: None declared by the authors.

Financial Disclosure: None declared by the authors.

Acknowledgements: None declared by the authors.

Author Contributions: Idea/Concept: GNA; Design: İÖ; Data Collection/Processing: FFA; Analysis/Interpretation: FFA; Literature Review: İÖ, FVB; Drafting/Writing: FVB; Critical Review: GNA.

\section{REFERENCES}

1. Chu DKW, Pan Y, Cheng SMS, Hui KPY, Krishnan P, Liu Y, et al. Molecular diagnosis of a novel coronavirus (2019-nCoV) causing an outbreak of pneumonia. Clin Chem. 2020;66(4):549-55.

2. who.int [Internet]. World Health Organization. WHO Director-General's opening remarks at the media briefing on COVID-19 - 11 March 2020. [Cited: 2021 Mar 11]. Available from: https://www.who.int/ director-general/speeches/detail/who-director-generals-opening-remarks-at-the-media-briefing-on-covid19---11-march-2020

3. Smith AC, Thomas E, Snoswell CL, Haydon H, Mehrotra A, Clemensen J, et al. Telehealth for global emergencies: Implications for coronavirus disease 2019 (COVID-19). J Telemed Telecare. 2020;26(5):309-13.

4. Portnoy J, Waller M, Elliott T. Telemedicine in the era of COVID-19. J Allergy Clin Immunol Pract. 2020;8(5):1489-91.

5. hrsa.gov [Internet]. Health Resources and Services Administration. Telehealth Programs. [Cited: 2021 Mar 08]. Available from: https://www.hrsa.gov/ruralhealth/telehealth

6. medicaid.gov [Internet]. Centers for Medicare and Medicaid Services. Telemedicine. [Cited: 2021 Mar 08]. Available from: https://www.medicaid.gov/ medicaid/benefits/telemedicine/index.html

7. gov.uk [Internet]. Public Health England. Coronavirus (COVID-19): What is social distancing? [Cited: 2021 Mar 08]. Available from: https://publichealthmatters. blog.gov.uk/2020/03/04/coronavirus-covid-19-whatis-social-distancing

8. World Health Organization (WHO) Regional Office for Africa. Atlas of African health statistics 2018: Universal health coverage and the sustainable development goals in the WHO African Region. Brazzaville: WHO Regional Office for Africa; 2018.

9. Doarn CR, Latifi R, Poropatich RK, Sokolovich N, Kosiak D, Hostiuc F, et al. Development and validation of telemedicine for disaster response: The North Atlantic Treaty Organization multinational system. Telemed J E Health. 2018;24(9):657-68.

10. Doarn CR, Latifi R, Hostiuc F, Arafat R, Zoicas C. A multinational telemedicine systems for disaster response: Opportunities and challenges. Amsterdam, Netherlands: IOS Press; 2017.

11. Zhao J, Zhang Z, Guo H, Li Y, Xue W, Ren L, et al. Ehealth in China: challenges, initial directions, and experience. Telemed J E Health. 2010;16(3):344-9.

12. McDowell JE, Hanna BM, McKeown GC, Tate S. Telehealth: A useful strategy in the management of COPD? Am J Respir Crit Care Med. 2009;179:A2380.

13. Koulouri A, Gourgoulianis K, Hatzoglou C, Roupa Z. Telemetric detection of chronic obstructive pulmonary disease and investigation of quality of life for people working in shipbuilding industry. Acta Inform Med. 2014;22(5):315-9.

14. Biermann E, Dietrich W, Rihl J, Standl E. Are there time and cost savings by using telemanagement for patients on intensified insulin therapy? A randomised, controlled trial. Comput Methods Programs Biomed. 2002;69(2):137-46.

15. Goldberg LR, Piette JD, Walsh MN, Frank TA, Jaski BE, Smith AL, et al. Randomized trial of a daily electronic home monitoring system in patients with advanced heart failure: the Weight Monitoring in Heart Failure (WHARF) trial. Am Heart J. 2003;146(4):705-12.

16. Inglis SC, Clark RA, McAlister FA, Ball J, Lewinter C, Cullington D, et al. Structured telephone support or telemonitoring programmes for patients with chronic heart failure. Cochrane Database Syst Rev. 2010;8:CD007228.

17. Kim HS, Shin SJ, Kim SC, An S, Rha SY, Ahn JB, et al. Randomized controlled trial of standardized education and telemonitoring for pain in outpatients with advanced solid tumors. Support Care Cancer. 2013;21(6):1751-9. 
18. Zhou X, Snoswell CL, Harding LE, Bambling M, Edirippulige S, Bai X, et al. The role of telehealth in reducing the mental health burden from COVID-19. Telemed J E Health. 2020;26(4):377-9.

19. Maunder RG. Was SARS a mental health catastrophe? Gen Hosp Psychiatry. 2009;31(4):316-7.

20. Rees CS, Maclaine E. A systematic review of videoconference-delivered psychological treatment for anxiety disorders. Aust Psychol. 2015;50(4):259-64.

21. Turgoose D, Ashwick R, Murphy D. Systematic review of lessons learned from delivering tele-therapy to veterans with post-traumatic stress disorder. J Telemed Telecare. 2018;24(9):575-85.

22. Backhaus A, Agha Z, Maglione ML, Repp A, Ross B, Zuest D, et al. Videoconferencing psychotherapy: a systematic review. Psychol Serv. 2012;9(2):111-31.

23. Kauer SD, Mangan C, Sanci L. Do online mental health services improve help-seeking for young people? A systematic review. J Med Internet Res. 2014;16(3):e66.

24. Nikolaidis Y, Efthymiadis G, Angelidis P. Quality assessment of a second opinion telemedicine service. Health Technol. 2019;9:659-78.

25. Lurie N, Carr BG. The role of telehealth in the medical response to disasters. JAMA Intern Med. 2018;178(6):745-6.

26. Klein BC, Busis NA. COVID-19 is catalyzing the adoption of teleneurology. Neurology. 2020;94(21):903-4.

27. Hollander JE, Carr BG. Virtually perfect? Telemedicine for COVID-19. N Engl J Med. 2020;382(18):1679-81.
28. Green T, Hartley N, Gillespie N. Service provider's experiences of service separation: the case of telehealth. J Serv Res. 2016;19(4):477-94.

29. Wade VA, Eliott JA, Hiller JE. Clinician acceptance is the key factor for sustainable telehealth services. Qual Health Res. 2014;24(5):682-94.

30. Edirippulige S, Brooks P, Carati C, Wade VA, Smith AC, Wickramasinghe $S$, et al. It's important, but not important enough: eHealth as a curriculum priority in medical education in Australia. $\mathbf{J}$ Telemed Telecare. 2018;24(10):697-702.

31. Prochaska JO, Velicer WF. The transtheoretical model of health behavior change. Am J Health Promot. 1997;12(1):38-48.

32. Marcus BH, Selby VC, Niaura RS, Rossi JS. Selfefficacy and the stages of exercise behavior change. Res Q Exerc Sport. 1992;63(1):60-6.

33. Lustria MLA, Noar SM, Cortese J, Van Stee SK, Glueckauf RL, Lee J. A meta-analysis of webdelivered tailored health behavior change interventions. J Health Commun. 2013;18(9):1039-69.

34. Noar SM, Benac CN, Harris MS. Does tailoring matter? Meta-analytic review of tailored print health behavior change interventions. Psychol Bull. 2007;133(4):673-93.

35. Rakowski W. The potential variances of tailoring in health behavior interventions. Ann Behav Med. 1999;21(4):284-9.

36. Dorsey ER, Topol EJ. State of Telehealth. N Engl J Med. 2016;375(2):154-61. 